\section{The multilevel effect of marketing activities on sales, revenue and profitability in a micro-enterprise}

\author{
Rafael Barreiros Porto \\ Rafaela da Rocha Costa \\ Eluiza Alberto de Morais Watanabe \\ University of Brasilia, Faculty of Economics, Administration, Accounting and \\ Public Policy Management, Administration Department, Brasilia, Brazil
}

Received on

02/23/2016

Approved on

$02 / 10 / 2017$

Responsible editor:

Prof. Dr. Guilherme Shiraishi

Evaluation process:

Double Blind Review

\begin{abstract}
Purpose - This study dynamically assessed the effectiveness of marketing activities in the generation of product sales, revenue, and profitability in a micro-enterprise, a context that lacks research in marketing.
\end{abstract}

Design/methodology/approach - A longitudinal multilevel study was conducted using daily panel data for 5,800 products sold and monthly time series on the business level, involving 26 months of commercial and financial records for a micro-enterprise (a drugstore). Panel and time series regressions were performed.

Findings - The research shows that (1) marketing activities, in particular price elasticity, quite accurately generate product sales, (2) the aggregated estimate of total marketing activities predicts monthly company revenue and profitability, and (3) in the investigated company, if marketing activities are intensified in the same proportion to increase costs in products and goods, they are not efficient in generating profit.

Originality/value - This research supports investigations concerning micro $\rightarrow$ macro level analysis relationships with commercial and financial data in order to merge marketing decisions to finance.

Keywords - Marketing activities; business performance; microenterprise; profitability and sales.

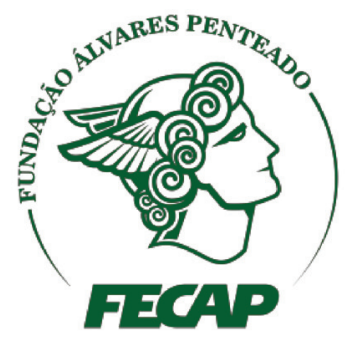

Review of Business Management

DOI:10.7819/rbgn.v19i65.2911 


\section{Introduction}

Marketing activity is characterized as being a management task that involves planning the conception of products, their price, promotions, and distributions to meet consumer demand (Wilkie \& Moore, 2007). It is a set of entrepreneurial actions that are part of the management process that connects a business with its consumers and can be configured in several ways (Finkelstein \& Peteraf, 2007). It is generally measured as an amount of managerial work executed in sales, converting input into output. In short, it is what marketing professionals do and is central to marketing concept from a managerial perspective (Nicolau, 2013).

The effectiveness of such activities in terms of revenue and profitability is a topic that brings together the interests of professionals and researchers from the business management field (Mintz \& Currim, 2013; Roberts, Kayande, \& Stermersch, 2013). However, due to the operational limitations involving how to measure activities and how to relate them to business performance indicators, researchers have made few advances in the scientific knowledge that could improve the effectiveness of marketing management.

Part of what is researched regarding this subject is related to the marketing costs (especially advertising) described in accounting information such as the company's income statement and balance sheet (Raman, Mantrala, Sridhar, \& Tang, 2012). This line of investigation has been rewarding (Guissoni \& Neves, 2013), but leads to general findings on the influence of marketing costs on financial performance without specifying which specific cost is responsible for variations in rates of returns. Moreover, these studies do not indicate the incidence or execution of an individual activity itself, but rather, the alleged costs connected to them (Ward, 2013). Thus, the true sources of the company's product and service sales, those that directly affect consumers, remain unknown.
The reason for the lack of studies directly investigating marketing activities and financial performance involves the differences between what is recorded and focused on company customer management and what is recorded for accounting and financial purposes (Hill, 2001; Ward, 2013). In general, business documents do not "talk" to each other and do not have the same purpose or target. Furthermore, there is the problem of directing the information: marketing activities are almost exclusively intended for managers to decide on the sale of products and accounting cost information is generally directed at decisions about the company's financial results (Monteiro \& Barbosa, 2011).

These difficulties are partially overcome when studies consider diverse levels of analysis (McDonald, Mouncey, \& Maklan, 2014): one that concerns a company's commercialized products and another that concerns the company as a whole, the latter encompassing the former. To bring forward this solution, studies need to investigate both levels of analysis, containing disaggregated (individualized) data regarding product commercialization and aggregated data regarding business financial performance.

This approach has come across obstacles, especially in the context of micro and small businesses (Brooks \& Simkin, 2011). These do not generally record their marketing activities with precision and their accounting information may not be audited regularly, which hampers investigations. However, the incidence of these companies in the Brazilian market is quite high (Sebrae, 2015) and they do, nonetheless, implement some marketing activities, controlling their financial operations to some degree.

The effects of implementing marketing activities to raise company sales and increase profitability for the owners of or partners in micro-businesses remains open for scientific research. To pave this way, the general aim of this paper is to dynamically assess the effectiveness of marketing activities in generating product sales, revenue, and elasticities in profitability in a microenterprise. 
To this end, we investigate (1) the effect of each marketing activity carried out by a micro-enterprise on sales, for each one of its daily commercialized products; (2) whether the entire set of marketing activities in an aggregated way explains monthly variations in revenue; and (3) whether these marketing activities explain monthly variations in sales returns (elasticities of profitability), comparing to the effect of product costs. Thus, the aim is to show a method for evaluating marketing activity returns in a small company.

\section{Marketing dynamics and the financial performance of small enterprises}

From a managerial perspective, what marketing professionals do is a set of actions that involve analyzing market opportunities, choosing target markets, developing marketing strategies/ programs, and organizing, implementing, and controlling marketing efforts (Zait, 2009). Marketing activities are generally analyzed via the execution of the marketing mix - product, price, place, and promotion (Asgarnezhad Nouri, Sanayei, Fathi, \& Kazemi, 2015). They are part of marketing capacities (e.g. adaptation of marketing process, use of market information to develop marketing processes, etc. - Vorhies, Orr, \& Bush, 2011).

Traditionally, studies that relate marketing activities with financial performance use the Compustat databases with data on Profit Impact of Marketing Strategy - PIMS (Boyd, Farris, \& Hildebrandt, 2004). The data are on a business strategy unit level for North American companies and provide information regarding relative market share, marketing costs, relative prices, relative product quality, introductions of new products, and product line innovations, etc.

Recent advances in the interface between marketing and finance have provided empirical evidence on the impact of a specific marketing activity on company performance, using real and not only North American longitudinal company data (Morgan, 2012). The Market Response Models - MRM (Hanssens, Parsons, \& Schultz, 2003) have been quite widely used since the end of the 1990s to explain the dynamics of the effects of marketing activities.

Some studies assess the effect of each marketing activity on product sales over time, by separating short and long term effects (Ataman, Van Heerde, \& Mela, 2010; Jandaghi, Amiri, Amini, \& Darani, 2011), and others investigate the dynamic effect of these activities on revenue, profitability, and value in the financial market (Feng, Morgan, \& Rego, 2015; Lima \& Porto, 2012; Mizik, 2014; Siddhanta \& Banerjee, 2014).

Specifically, Hanssens and Dekimpe (2008) support these studies by reporting how marketing investment evaluations are useful not only for marketing functions, but also for the entire company. They use contextual explanations involving the Chain of Marketing Productivity - CMP (Rust, Ambler, Carpenter, Kumar, \& Srivastava, 2004) and flow metrics directed towards the shareholder from Srivastava, Shervani, and Fahey (1998). To ensure higher or quicker and more sound profitability, they propose that marketing investment can generate immediate results in company revenue flow and in building brands and customer base, which are not very visible in the short run.

In turn, Mizik (2014) demonstrates through aggregated company level data that only a small portion of the total financial impact (profit) of brand equity (one of the most strategic marketing activities) is revealed immediately (current year), whereas most is realized in subsequent years. This result is consistent with the proposal from Hanssens and Dekimpe (2008) regarding the effect of brand building being more visible in the long run; however, Mizik (2014) found a lot of heterogeneity in these effects (some companies only presented immediate brand equity effects while others only presented them in the long run).

Nonetheless, the effects of marketing on the finances of micro and small businesses are 
quite distant from the reality that the PIMS, RMR, and CMP studies have investigated. The owners or managers of small enterprises are generally not trained in marketing and hardly use professional marketing techniques (Hankinson, 1991). For example, aspects such as the customer relationship, word of mouth, and dialogue with clients are practiced by managers or owners without the use of professional marketing techniques and any awareness of these being systematized marketing actions (Coelho, de Miranda, Camargo Filho, Freitag, \& de Almeida, 2015).

In broader terms, McCartan-Quinn and Carson (2003) list some of the marketing characteristics that the small businesses have in common: (1) the limited physical and financial resources results in asymmetrical and limited marketing actions; (2) generally, they do not systemically record the marketing actions implemented; (3) they do not trade their shares on a stock exchange; (4) because they are not mandatorily audited, some of the companies do not have reliable accounting data; (5) many do not have a strong brand or market power; and (6) the marketing actions implemented generally aim for immediate increases in revenue and accounting profit, and these actions may often be ineffective.

The greatest incidence of small enterprises is in commercial retail. Besides the previous features, these companies are characterized for: (1) having few sales outlets, if not only one; (2) rarely engaging in promotional activities and often limiting themselves to identifying the name of the shop or sporadic actions involving posters, leaflets, or gifts; (3) there is little variety in product assortment or little variety of brands, with cases of companies that sell only one product; (4) they regularly use price reduction strategies, despite often not measuring the returns from these actions; (5) they occasionally renovate the store externally or internally; and (6) they may make use of a sales team that earns via sales commissions (Braghin, Higashibara, de Freitas, Catuchi, \& Mancini, 2008; Conselho Federal de Farmácia
CFF, 2008; Guia das Farmácias, 2014; Oliveira Filho, 2013).

All these limitations have led to a loss of opportunity for the managers or owners to operate in the market in terms of obtaining scale and an impact on financial indicators. McCartan-Quinn and Carson (2003) concluded that the marketing practices of small companies are informal, intuitive, and focused on sales. This situation has required considerable effort on behalf of researchers to understand the effects of marketing on financial performance in these small enterprises.

In developing countries such as Brazil, small enterprises systematically lack recorded marketing data. Thus, some studies investigating the reality of small companies have used a cross section involving questionnaires to measure marketing activities [e.g. asking for comparisons with competitors regarding marketing capacities using Likert type scales (Floriani \& Fleury, 2012; Vorhies, Orr, \& Bush, 2011)] and company performance [e.g.: if financial performance is better or worse than competitors or how much respondents say they used a particular performance metric to evaluate results (Akroush, 2011; Mintz \& Currim, 2013)].

Additionally, multivariate analyses are rare in the studies involving this theme in Brazil (Sarquis et al., 2016), and do not systematically demonstrate marketing activity derived predictors of financial success for small enterprises. Because small companies focus on sales [and not so much on profitability maximization (McCartan-Quinn \& Carson, 2003)], managers' or owners' concerns with growing revenue are obvious. However, the effect of the entire group of marketing actions on the sales of each product, company turnover, and profitability as a whole is not evident for entrepreneurs or managers. This requires a longitudinal analytical study of this effect in terms of both revenue and profitability, to unveil possible instabilities.

Even for the reality of a small retail company, the difference between levels of analysis 
for marketing activities and financial metrics becomes central to discuss the effectiveness of marketing. In general terms, a small commercial company worries a lot about selling suppliers' products, stimulating sales using promotional material, increasing product assortment, product pricing alterations, offering more than one form of payment, changing the store ambience, and spending on sales teams, where applicable (Grewal, Levy, \& Kumar, 2009; Newman \& Cullen, 2002; Runyan \& Droge, 2008). These actions aim to stimulate the demand for some product sold on a daily basis. Nevertheless, the traditional revenue and profit/loss measurements are accounting related and refer to companies as a whole and do not capture the dynamics and heterogeneity of data. This makes it difficult to test and analyze effectiveness, and requires comparisons between diverse levels of analysis.

\section{Research model and hypotheses}

The importance of using multilevel models in large companies has been well documented (Hitt, Beamish, Jackson, \& Mathieu, 2007). However, researchers addressing company performance and marketing activities have used little knowledge derived from models that cover more than one level simultaneously (Hansen \& Wernerfelt, 1989; Wieseke, Lee, Broderick, Dawson, \& Van Dick 2008). This has generated partial knowledge regarding the real impact of explanatory variables over an explained variable (e.g. financial results), particularly when these explanatory variables are derived from different levels of analysis. The application of multilevel models in small companies is rare.

The models can contain different combinations of variables (Mayntz, 2004): (1) micro-micro, when the explanatory and explained variables are all on the lower level of analysis; (2) macro-micro, when the explanatory variables are on the higher level and the explained ones on the lower level; (3) micro-macro, when the explanatory variables are on the lower level and the explained ones on the higher level; and (4) macro-macro, when the explanatory and the explained variables are on the higher level. Only models 2 and 3 are multilevel, while 1 and 4 are treated within the same level of analysis.

Isaeva, Safiullin, Bagautdinova, and Shaidullin (2013) suggest that in studies regarding competitive performance within economic systems, the objects of multilevel research can be in rising order: products, companies, sectors (or industries), and countries (or regions). This study presents a model on two levels (Figure 2), namely the product level and company level, and is characterized as micro-micro and micro-macro in a dynamic form (over time).

In the model in Figure 2, the micro-micro level is characterized by the daily marketing activities (for each product brand) that influence the explained variable, daily sales (for each product brand) for a small retail company. Thus, each marketing activity carried out for the product brands (price in log, payment via credit, sales commission, change in store ambience, promotional materials, and increased product assortment) is expected to exert a positive influence over products sales (Ataman, Van Heerde, \& Mela, 2010; Bijmolt, Heerde, \& Pieters, 2005; Klapper \& Zenetti, 2012; Mishra, Sinha, \& Koul, 2014; Morgado \& Benito, 2015; Porto \& Oliveira-Castro, 2015; Porto \& Silva, 2014; Shields, 2006).

These activities are very commonly implemented by small companies (Newman \& Cullen, 2002; Runyan \& Droge, 2008) and this was the main reason behind choosing them. Moreover, these activities vary over time and aim to immediately increase revenue, which is typical of small companies with little concern for creating or sustaining brands to generate long term returns (Hanssens \& Dekimpe, 2008).

It bears mentioning that in this study marketing activities are not measured by costs (Raman et al, 2012), but instead by the execution period for each action. However, sales are measured daily in financial value. Thus, the relationship between executing actions and sales 
should be linear and positive. Given that managers or owners execute these actions to increase supplier product sales, Hypothesis $1\left(\mathrm{H}_{1}\right)$ can be thus formulated: the marketing activities generate a positive effect on the daily sales of the products sold by the small company.

Confirming $\left(\mathrm{H}_{1}\right)$ is necessary so that Hypotheses 2 and 3 may be formulated. The micro-macro relationship in this study has two explained variables on the business (macro) level: monthly sales revenue and monthly company profitability (representing both financial results variables). The micro level explanatory variable (monthly estimate of marketing activities) represents the total behavior of the firm involving its product marketing, which represents a logic contrary to that which multilevel studies generally test (Wieseke et al., 2008).

The monthly estimate of marketing activities is characterized by the sum of the score (Total Xbeta) for all daily product marketing activities aggregated monthly. This reduces the heterogeneity of the micro level data, but allows for a general view of marketing activities. This aggregation is routine in market modeling for strategic marketing decisions (Leeflang, Wieringa, Bijmolt, \& Pauwels, 2015).

The modeling can be dynamic and analyzed via stationary time series. Hanssens et al. (2003) indicates that aggregation alters the functional form of disaggregated data, thus generating possible specification errors, and suggests that, as a rule, when it is applied to sales, any aggregation over time should correspond to a product's purchase cycle.

However, correspondence to a product's purchase cycle is not needed if different levels of analysis are considering dynamically. Purchase cycle should be handled at the micro level of daily product sales, which is useful for marketing (commercial) decision making. However, it is not needed at the macro level of company decisions, which is generally monthly for cash flow purposes (Irvine \& Pontiff, 2009). Therefore, Hypothesis $2\left(\mathrm{H}_{2}\right)$ and Hypothesis $3\left(\mathrm{H}_{3}\right)$ can be formulated: the aggregated estimate of marketing activities dynamically generates a positive result in revenue $\left(\mathrm{H}_{2}\right)$ and in company profitability $\left(\mathrm{H}_{3}\right)$, just as they do at the micro-micro level these activities have an impact on product sales.

Marketing activity scores on the macro level can cause a non-significant (or even negative) effect on revenue and on profitability due to spurious effects. In turn, these effects can occur due to specification or measurement errors regarding the micro level variable to be aggregated (Croon \& Van Veldhoven, 2007).

One way to avoid this and capture variables on a lower level in order to forecast a company's performance (higher level) is by using latent scores for the explanatory variables originating from regression parameters (Croon \& Van Veldhoven, 2007). In this study, this was done by calculating the aggregated estimate for all of the marketing activities carried out for the entire range of product brands sold monthly, which eliminates the possibility of spurious effects. Monthly aggregation of this score was necessary because the company performance variables are calculated monthly for management purposes, which led to the conception of the macro level in this study.

Also on the micro-macro level, the macro level explanatory variable - monthly cost of products - represents the cost of the physical resources for the company to carry out the retail business. As it is subtracted from revenue to generate net profit, Hypothesis $4\left(\mathrm{H}_{4}\right)$ can be thus formulated: the monthly cost of products exerts a dynamic, negative effect over profitability. 


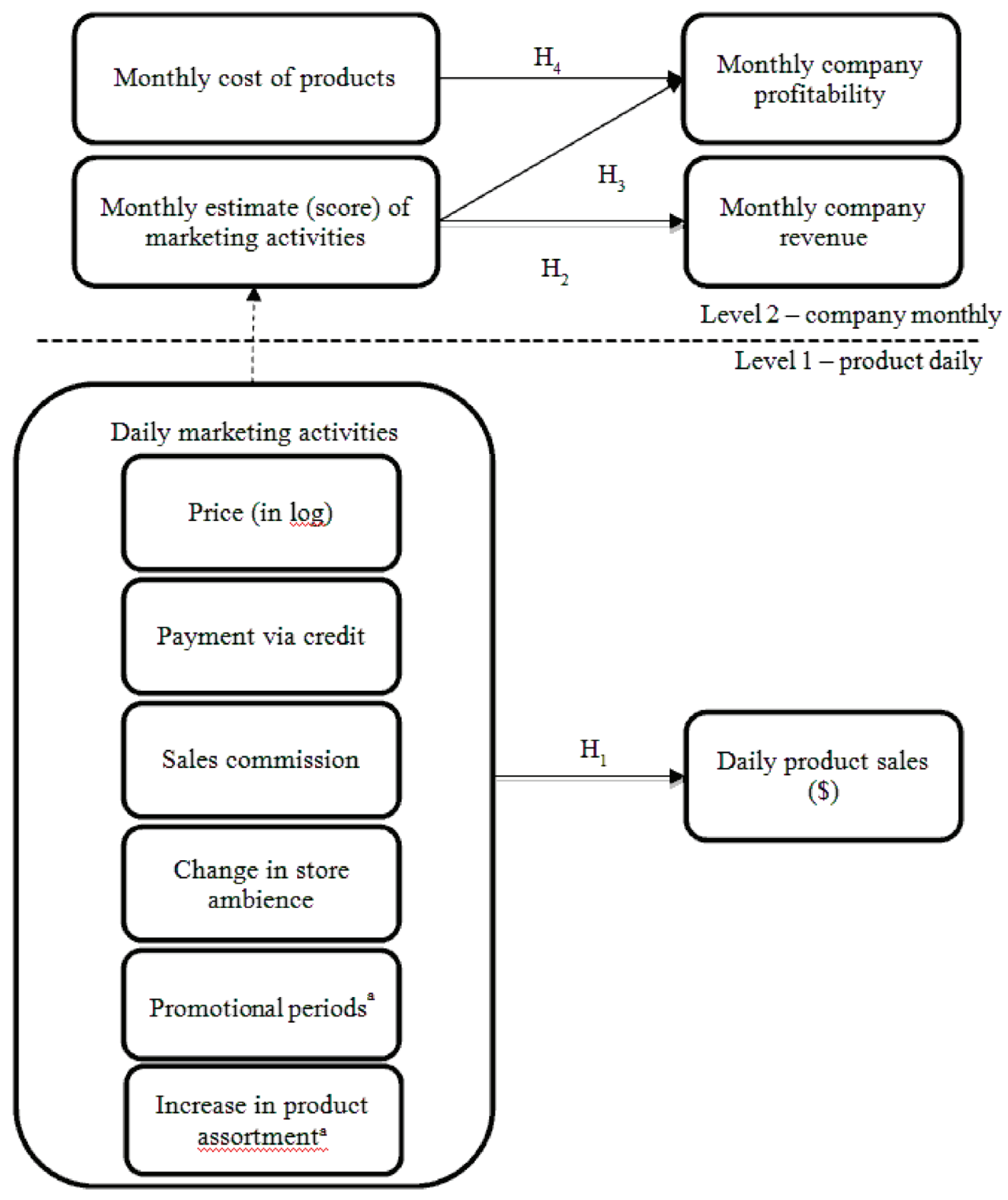

Figure 1. Two level model of marketing activity effectiveness in terms of product sales, revenue, and the profitability of the micro-enterprise.

Source: Elaborated by the authors.

${ }^{\text {a }}$ For certain products only.

\section{Method}

\section{I Framework}

This study ${ }^{1}$ simultaneously uses product panel data over 790 days (micro-micro level) and a 26-month time series for the investigated financial indicators of the company (micro-macro level). Panel data studies enable inferences to be made regarding temporal cause and effect (Cozby, 2006), making them natural quasi-experiments (Stock \& Watson, 2004). The absence (or low magnitude) of an explanatory variable and its 
subsequent presence (or high magnitude) is similar to experiments with repeated measurements, but it is manipulated naturally. In this paper, the manipulation is carried out by the micro-business managers themselves.

The study is quasi-experimental and involves a longitudinal section with two levels of analysis: micro level (product daily) and macro level (company monthly). The manipulated (explanatory) variables were the marketing activities implemented daily by the company to sell its products (micro level) and the aggregated estimates of these marketing activities on the macro level. We chose to insert a covariate (cost of products) on the macro level of the analysis to identify more clearly the effectiveness of the aggregated estimates of marketing activities. The explained variables were the daily sales of each product sold (micro level), monthly company revenues, and the monthly profitability indicator, both on a macro level.

\subsection{Sample and data collection}

The company is family run, was created in 1991, and is located in the Federal District of Brazil. It belongs to the pharmaceutical retail area and has six employees, of which four are sales assistants, one is a pharmacist, and one is a bookkeeper. It is open to the public from Monday to Sunday, from 8 am to $10 \mathrm{pm}$. The company carries out its management controls using a specific software package for drugstores, called Microfarma, which classifies products into: perfumery, generic drugs, ethical drugs and natural food, and from which the research data was extracted.

In order to confirm that the marketing activities already recorded in the software were carried out, the researchers asked for payment receipts showing the exact moment each activity was carried out (e.g. change in store ambience, promotional periods, etc.). Changes in store ambience were both internal (changes to floor and walls) and external (changes to storefront) and occurred during a month of operations.
Moreover, the company bookkeeper provided reports containing turnover, taxes, social security contributions, and purchases. To complete this information, the owner provided data such as fees and administrative expenses. With all these data, net revenue and monthly returns on sales could be calculated.

The company analyzed has an annual gross revenue of less than $\mathrm{R} \$ 360,000.00$ and is thus classified as a retail sector micro-business (Supplementary Law N. 139, 2011). A total of 5,800 products (bar-coded packages) were sold over 790 days, including samples of each packaging for all the available brands in the following categories: cosmetics, general usage medicines and red and black labelled (laboratory and generic) drugs, personal hygiene, perfumery, and natural food. On the microanalysis level, the sample was composed of 57,903 receipts for products sold, whereas on the second level it was composed of 26 months of the company's recorded commercial and financial data.

On the microanalysis level, the sample power for multiple regression with a small size effect $\left(\mathrm{F}^{2}=0.02\right)$, with a probability error $\alpha=0.05$, and with seven predictors, was equal to $99.99 \%$, and more than enough to minimize Type 2 error. On the second analysis level, for both the relationships tested, the sample power for multiple regression with a large effect $\left(\mathrm{F}^{2}=\right.$ 0.35 ), with a probability error $\alpha=0.05$, and with two predictors, was equal to $89.99 \%$, and enough to minimize Type 2 error. Nonetheless, for samples below 50 on the macro level, Maas \& Hox, (2005) suggest that standardized errors in macro level estimates are biased, characterizing a possible sample limitation.

\subsection{Descriptive analysis of variables}

Table 1 shows the variables, their operational definitions, and descriptive analysis. It is perceived that besides displaying revenue values typical of a retail micro-business, it has, on average, good returns on sales, with a low standard error. 
Also in Table 1, it is observed that the estimates that represent the company`s marketing activities on a daily product commercialization level presented a high standard deviation, which means that there is a high spread in their use between products. But the spread in these estimates is high over the months (macro level), which means that the company reasonably maintains the same marketing activities for the products over the months.

It should be highlighted that the nonmetric marketing activity variables were treated as dummies in the analysis. Thus, promotional periods were given code 1 if they were in the period and 0 otherwise, changes in store ambience were given code 1 if they were in the post change period and 0 otherwise, and periods of increased product assortment were given code 1 if they were in the period and 0 otherwise.

It was observed that regarding promotional periods, respiratory tract drugs, bronzers, sun blocks, and moisturizers were considered. With regard to product assortment, the nail varnish assortment was analyzed, since during the period it was the only one that presented any alteration (increased offer in packaging and brands).

Table 1

\section{Descriptive analysis of the data from the study}

\begin{tabular}{|c|c|c|c|c|}
\hline Variable & Operational definition & Average & $\begin{array}{l}\text { Standard } \\
\text { Deviation }\end{array}$ & $\%$ \\
\hline Annual gross revenue & $\begin{array}{l}\text { Sum of multiplying the sales of all products by their sales prices } \\
\text { for one year }\end{array}$ & $322,652.35$ & $77,206.12$ & \\
\hline Monthly net revenue & Monthly gross revenue minus returns, discounts, and sales taxes & $26,164.40$ & $6,079.74$ & \\
\hline Monthly cost of products & $\begin{array}{l}\text { Initial stock for the month plus purchases made during the } \\
\text { month minus final stock at month end }\end{array}$ & $22,513.64$ & $2,153.17$ & \\
\hline Monthly net profit & $\begin{array}{l}\text { Operating profit minus non-operating expenses minus } \\
\text { employee profit sharing minus social security contributions }\end{array}$ & $5,930.86$ & $2,218.09$ & \\
\hline $\begin{array}{l}\text { Returns on sales } \\
\text { (profitability) }\end{array}$ & Net profit divided by net revenue for one month & 0.25 & 0.12 & \\
\hline Daily sales in the company & $\begin{array}{l}\text { Sum of multiplying one day of sales of all products by their } \\
\text { sales prices }\end{array}$ & 704.56 & 251.68 & \\
\hline Daily sales per product & $\begin{array}{l}\text { Sum of multiplying one day of sales of each product by their } \\
\text { sales price }\end{array}$ & 12.22 & 2.39 & \\
\hline $\begin{array}{l}\text { Price of the products for one } \\
\text { day }\end{array}$ & Product sales price (bar code) for one day & 9.69 & 11.54 & \\
\hline $\begin{array}{l}\text { Sales assistant commission for } \\
\text { one day }\end{array}$ & Sum of the amount paid for the product sold in one day & 58.56 & 119.03 & \\
\hline $\begin{array}{l}\text { Percentage of payments made } \\
\text { via client credit for one day }\end{array}$ & $\begin{array}{l}\text { Amount of payment via credit card for each product divided by } \\
\text { the total amount of client payments for each product in one day }\end{array}$ & 14.54 & 7.43 & \\
\hline $\begin{array}{l}\text { Estimate of marketing activities } \\
\text { per product for one day }\end{array}$ & $\begin{array}{l}\text { Estimates (Xbeta) of all company marketing activities per } \\
\text { product in one day }\end{array}$ & 0.90 & 0.99 & \\
\hline $\begin{array}{l}\text { Promotional period for } \\
\text { respiratory tract drugs }\end{array}$ & $\begin{array}{l}\text { Total number of days that the drugs were on sale divided by the } \\
\text { total number of days }\end{array}$ & & & 23.30 \\
\hline $\begin{array}{l}\text { Promotional period for } \\
\text { bronzers, sunscreens, and } \\
\text { moisturizers }\end{array}$ & $\begin{array}{l}\text { Total number of days that the cosmetics were on sale divided by } \\
\text { the total number of days }\end{array}$ & & & 19.60 \\
\hline Change in store ambience & $\begin{array}{l}\text { Total number of days that the company operated with floor, wall, } \\
\text { and storefront changes divided by the total number of days }\end{array}$ & & & 69.40 \\
\hline $\begin{array}{l}\text { Increase in nail varnishes } \\
\text { assortment }\end{array}$ & $\begin{array}{l}\text { Total number of days that the company operated with an } \\
\text { increased variety of nail varnishes divided by the total number } \\
\text { of days }\end{array}$ & & & 84.90 \\
\hline
\end{tabular}




\subsection{Analysis procedure}

In order to make the data analyses on two analysis levels possible, three regressions were carried out (Stock \& Watson, 2004). The first, on the micro-micro level (product daily time series panel data), in which the sales of each product is the explained variable and each marketing activity present in the research model (Figure 1) the explanatory variables. Equation 1 illustrates the relationship tested. The Arellano panel data model with fixed effects and robust errors was used. The explained variable did not have normal distribution or the same variance error, thus requiring it to be transformed.

Equation 1

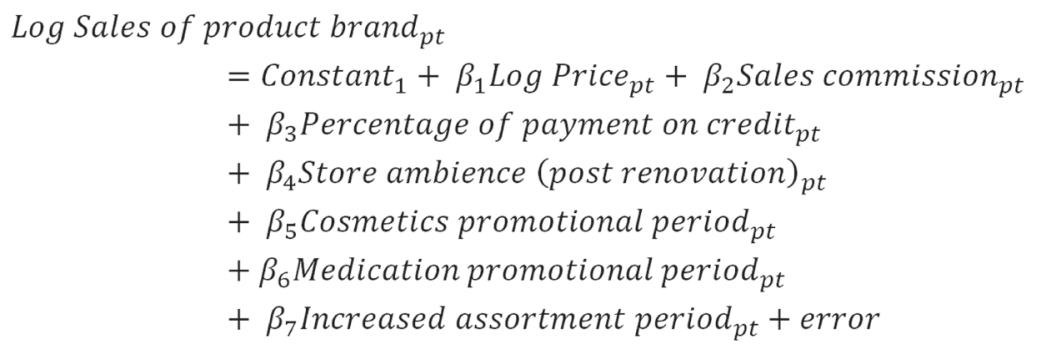

where $p=$ each bar code commercialized and $t=1,2,3 \ldots, x$.

The sales of each product were initially divided by the average for each one during the period analyzed and their natural logarithms were subsequently extracted. This gave the variable normal distribution (Kolmogorov-Smirnov = $0.1 ; \mathrm{p}>0.05$ ) with the same error variance (Wald Chi Squared $=46.86 ; \mathrm{p}>0.05)$. Interpreting the change in the value of sales then involves percentage points (above or below average sales). This also occurred with the explanatory variable, product sales price. Its transformation into a natural logarithm then allowed for price-revenue elasticity to be analyzed.

The model did not present multicollinearity problems (VIF < 2.4) and after considering the panel data structure it did not present serious problems of autocorrelation of the explained variable (Durbin Watson $=1.79)$. The intercepts between the products were different $(\mathrm{p} \leq 0.01)$ and the diagnostic test for the panel data model found that the MQO cluster model was not adequate, thus validating the alternative hypothesis that the fixed effect panel data structure was adequate ( $\mathrm{p}$ $\leq 0.01)$.

The second regression analysis is the micro-macro one, for which the explanatory variable was the estimate of marketing activities on the lower level (derived from the first regression), aggregated for the whole company monthly. The focus is on identifying whether marketing activities can be good predictors of revenue on the monthly business level. Equation 2 illustrates the tested relationship.

\section{Equation 2}

Company revenue $_{t}=$ Constant $_{1}+\beta_{1}$ Xbeta of marketing activities I $_{t}+$ error

Where, $\mathrm{t}=1,2,3 \ldots \mathrm{x}$. 
Due to the Durbin-Watson Test finding autocorrelation problems (0.35), time series regression was chosen. This regression made it possible to discover possible dynamic effects of the marketing activities implemented by the microenterprise on monthly revenue. The explained variable (monthly net revenue) presented normal distribution (Kolmogorov-Smirnov $=0.2$; $\mathrm{p}>0.05)$. The relationship is linear $(\mathrm{LM}=0.001$; $\mathrm{p}>0.05)$, with adequate specification $(\mathrm{F}=2.08$; $\mathrm{p}>0.05$ ), without heteroscedasticity (White Test $\mathrm{LM}=2.75 ; \mathrm{p}>0.05$; Breusch Pagan Test
$\mathrm{LM}=0.79 ; \mathrm{p}>0.05$ ), and with residual normality $($ Chi Squared $=5.62 ; \mathrm{p}>0.05)$.

Finally, the third regression analysis is also micro-macro, in which the explanatory variables are the estimates of marketing activities on the micro level (aggregated score), and with a macro level covariate (monthly cost of products). The focus is on identifying whether the marketing activities can be good predictors of returns on sales (profitability) on the company's monthly level, controlling the effect of costs of products. Equation 3 illustrates the tested relationship.

Equation 3

Log Company profitability

$$
\begin{aligned}
& =\text { Constant }_{1}+\beta_{1} X \text { Log Xbeta ofmarketing activities }_{t} \\
& +\beta_{2} \text { Log Cost of products }_{t}+\text { error }
\end{aligned}
$$

Where, $\mathrm{t}=1,2,3 \ldots, \mathrm{x}$.

Due to the Durbin-Watson Test finding autocorrelation problems (0.55), time series regression was chosen. This regression made it possible to discover possible dynamic effects of the marketing activities implemented by the microenterprise on profitability.

The explained variable (returns on sales) did not present normal distribution (KolmogorovSmirnov $=0.45 ; \mathrm{p}<0.01)$, requiring it to be transformed into a logarithm. Moreover, the two explanatory variables were transformed into logarithms to illustrate changes in elasticity and to standardize the interpretation. The relationship of the explanatory with the explained one is linear $(\mathrm{LM}=3.59 ; \mathrm{p}>0.05)$, with adequate specification $(\mathrm{F}=1.85 ; \mathrm{p}>0.05)$, without multicollinearity $(\mathrm{VIF}<2)$, without heteroscedasticity (White Test $\mathrm{LM}=3.36 ; \mathrm{p}>0.05$; Breusch Pagan Test $\mathrm{LM}=$ 1.67; $\mathrm{p}>0.05$ ), and with residual normality (Chi Squared $=5.98 ; \mathrm{p}>0.05)$. However, there is a unit root both in the explained variable and in the explanatory variables (Augmented DickeyFuller Test with constant and tendency p > 0.05), requiring the first difference for each variable to be generated aiming to eliminate non-stationarity effects.

\section{Results}

Initially, the result of the micro-micro analysis is revealed (products daily panel data), in which the explained variable is the sales of each product and the explanatory variables are each marketing activity implemented by the company daily. Subsequently, the first result of the micromacro relationship is shown: the effectiveness of the monthly estimate of marketing activities in terms of the retail micro-business' revenue. This section ends by demonstrating the second micro-macro relationship: the effectiveness of the monthly estimate of marketing activities in terms of the retail micro-business' profitability, comparing with the effect of costs of products.

\section{I The effect of marketing activities on a company's daily product sales}

All the analyzed company's marketing activities were effective in increasing the sales 
of each product; however, some of them had a tenuous effect (see Table 2). All in all, they presented good explained variance both between products $\left(\mathrm{R}^{2}=80.58 \%\right)$ and within product $\left(\mathrm{R}^{2}\right.$ $=80.26 \%)$ over the 790 consecutive days.

Product price was the main influencer of sales $(\mathrm{B}=0.853 ; \mathrm{p}<0.01)$. As both variables are in natural logarithms, there is price-sales elasticity. Increasing company product price by $1 \%$ generates a $0.85 \%$ increase in product sales revenue. In other words, in general, prices practiced tend to be inelastic in terms of sales.

Altering the store ambience (altering the storefront, floor, internal and external identification) generates the second biggest effect on sales $(0.137 \%$ increase). The period in which the assortment of a high rotation product (nail varnish) was increased generated the third biggest effect on sales $(0.070 \%$ increase), followed by the percentage of payments carried out via credit (0.048\% increase). The promotional period for respiratory tract drugs generated an increase of $0.021 \%$, the promotional period for cosmetics generated a $0.016 \%$ increase, and finally, the increase in sales commission for products sold in the store generated a $0.002 \%$ increase.

Table 2

Effect of marketing activities on product sales (micro-micro)

\begin{tabular}{|c|c|c|c|c|}
\hline \multirow{2}{*}{ Marketing activities } & \multirow{2}{*}{$\begin{array}{l}\text { Estimate of fixed } \\
\text { effect }\end{array}$} & \multirow{2}{*}{$\begin{array}{l}\text { Standard } \\
\text { Error }\end{array}$} & \multicolumn{2}{|c|}{ 95\% Confidence Interva } \\
\hline & & & Low & High \\
\hline Intercept & $-2.01^{*}$ & 0.01 & -2.03 & -2.00 \\
\hline Product price (in log) & $0.853^{*}$ & 0.00 & 0.85 & 0.86 \\
\hline Sales commission & $0.002^{*}$ & 0.00 & 0.00 & 0.00 \\
\hline$\%$ of payment on credit & $0.048^{*}$ & 0.01 & 0.04 & 0.06 \\
\hline Store ambience (after change) ${ }^{\mathrm{a}}$ & $0.137^{*}$ & 0.01 & 0.12 & 0.14 \\
\hline $\begin{array}{l}\text { Promotional period (sun block, bronzer, sunscreen and } \\
\text { moisturizer) }\end{array}$ & $0.016^{*}$ & 0.01 & 0.01 & 0.03 \\
\hline Promotional period (respiratory tract drugs) & $0.021^{*}$ & 0.01 & 0.01 & 0.03 \\
\hline Increased period assortment (nail varnishes) & $0.070^{*}$ & 0.01 & 0.05 & 0.09 \\
\hline $\mathrm{R}^{2}$ Between & \multicolumn{4}{|c|}{$80.58 \%$} \\
\hline $\mathrm{R}^{2}$ Within & \multicolumn{4}{|c|}{$80.26 \%$} \\
\hline BIC (reference - only constant $=128,782.80)$ & \multicolumn{4}{|c|}{$53,610.80$} \\
\hline a: in relation to the period before changing the store an & & & & \\
\hline
\end{tabular}

$* \mathrm{p} \leq 0.01$

Examples of the effect of these activities taken altogether over sales can be seen in Figure 2. Both axes are in logarithms (log-log model), which enables the elasticity of the entire group of marketing activities (horizontal axis) in terms of sales (vertical axis) to be discovered.

In Graph A, the effect of the marketing activities over sales of the Active Bloc cosmetic bronzer can be perceived. This is also the case in Graph B for Benegrip general use sachet drugs, in Graph C for Puran T4 red label drug, and in
Graph D for Palmolive kids soap hygiene product. All have a high $\mathrm{R}^{2}$, showing that the line adjusts well to the data.

Each point represents a day of sales of these products. Some products are sold routinely (Benegrip), while others are sold less frequently (Palmolive kids). By using these marketing activities, the retail micro-enterprise, in this case, stimulates an increase in the sales of these and other products. 
Graph A

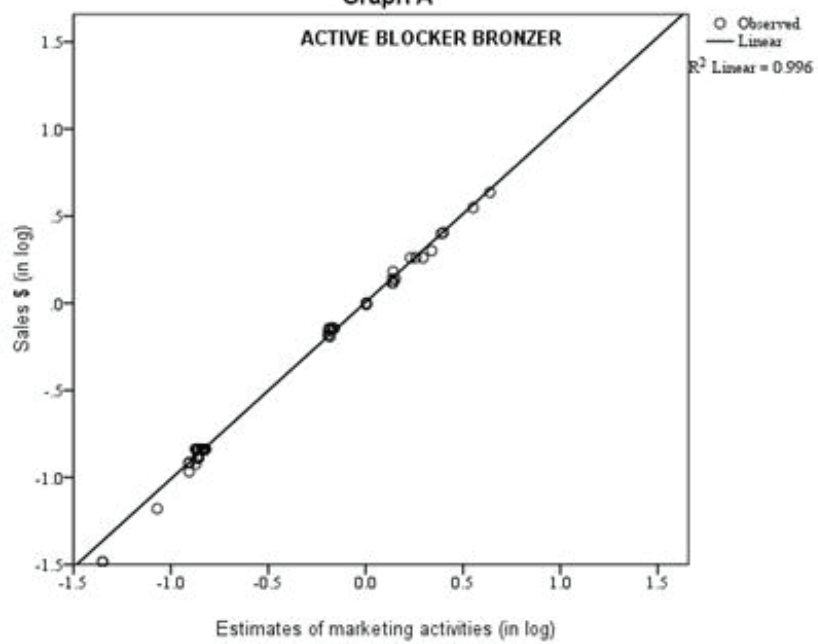

Graph C

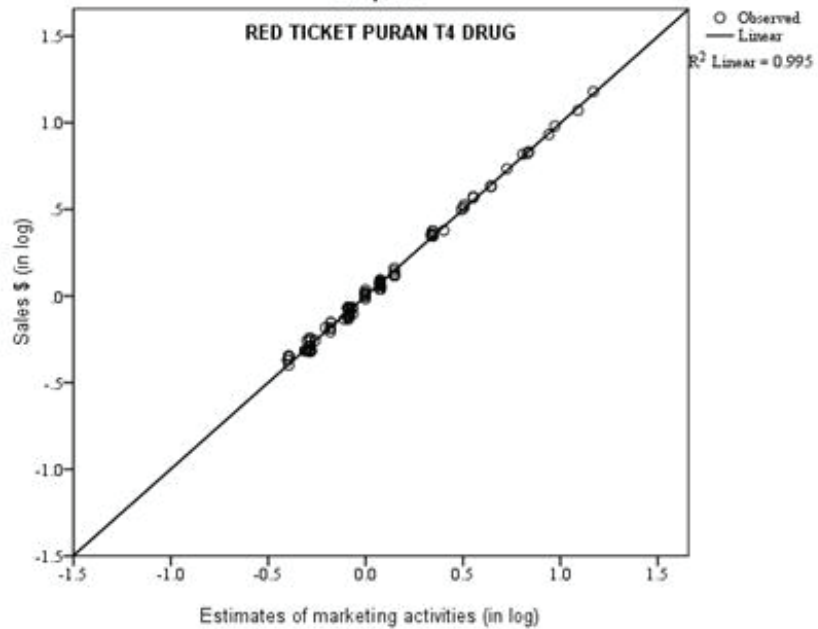

Graph B

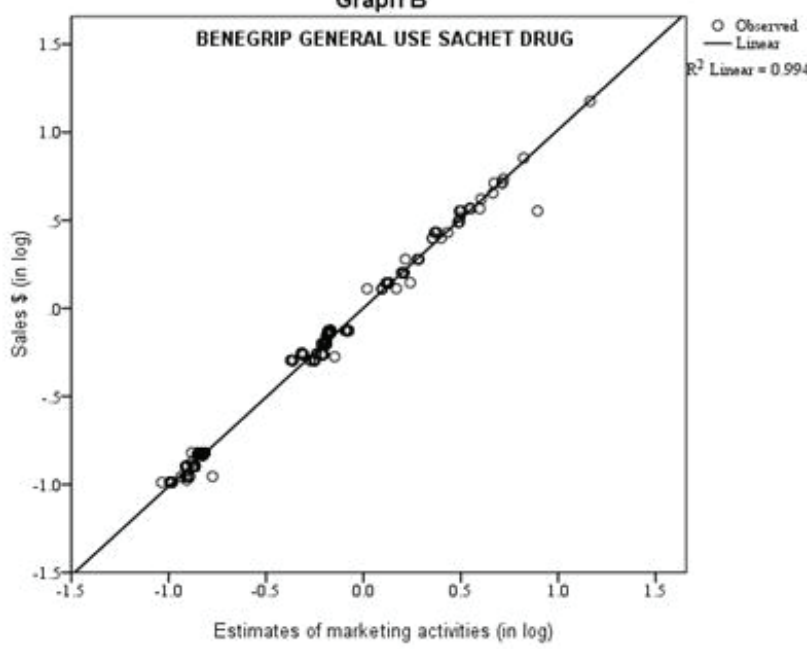

Graph D

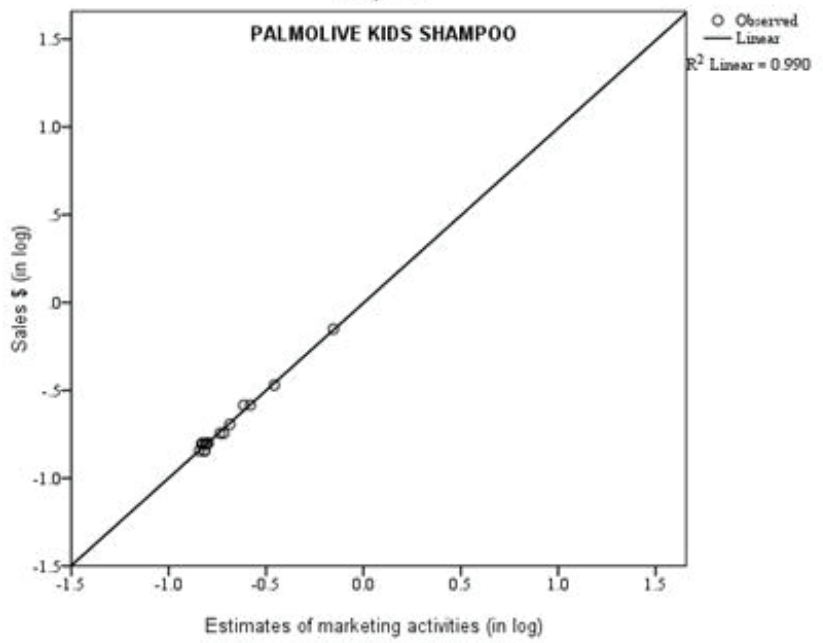

Figure 2. Example of graphs showing the effect of marketing activities on product sales.

Source: Database

\subsection{Effect of monthly estimates of marketing activities on revenue}

By aggregating the estimates of the marketing activities monthly, they also generate effects on aggregated sales (revenue) per month. A one point increase in the monthly estimate generates an increase of 5.12 times in monthly revenue (Table 3 ). The model in monthly time series presented optimal adjustment $\left(\mathrm{R}^{2}\right.$ stationary $=95.80 \%$ ), which means that, dynamically, the marketing activities generate effects on revenues. However, the effect is immediate. That is, in the same month as the marketing activities are implemented, an increase in revenue is also found. Short-term and long-term effects were not detected. For the next month to have an increase in revenue, other marketing activities are needed in that month. 
Table 3

Effect of estimates of marketing activities on company revenue (micro-macro)

\begin{tabular}{lcc}
\hline & \multicolumn{2}{c}{ EV: Monthly revenue } \\
\cline { 2 - 3 } & Estimate & Standard Error \\
\hline Constant & $20,987.80^{*}$ & $1,488.99$ \\
Monthly company marketing activities (in log) & $5.12^{*}$ & 0,50 \\
R $^{2}$ Stationary & \multicolumn{2}{c}{$95.80 \%$} \\
Bic Normalized & 13.92 \\
Ljung-Box Q (18) & $19.74(\mathrm{p}>0.05)$ \\
\hline
\end{tabular}

${ }^{*} \mathrm{p} \leq 0.01$

Graph E (Figure 3) illustrates the dynamics of the relationship between the variables. Almost perfect adjustment of the estimates to monthly net revenue is observed. Therefore, marketing activities generate a positive effect on the revenue on the retail of the micro company's sales.

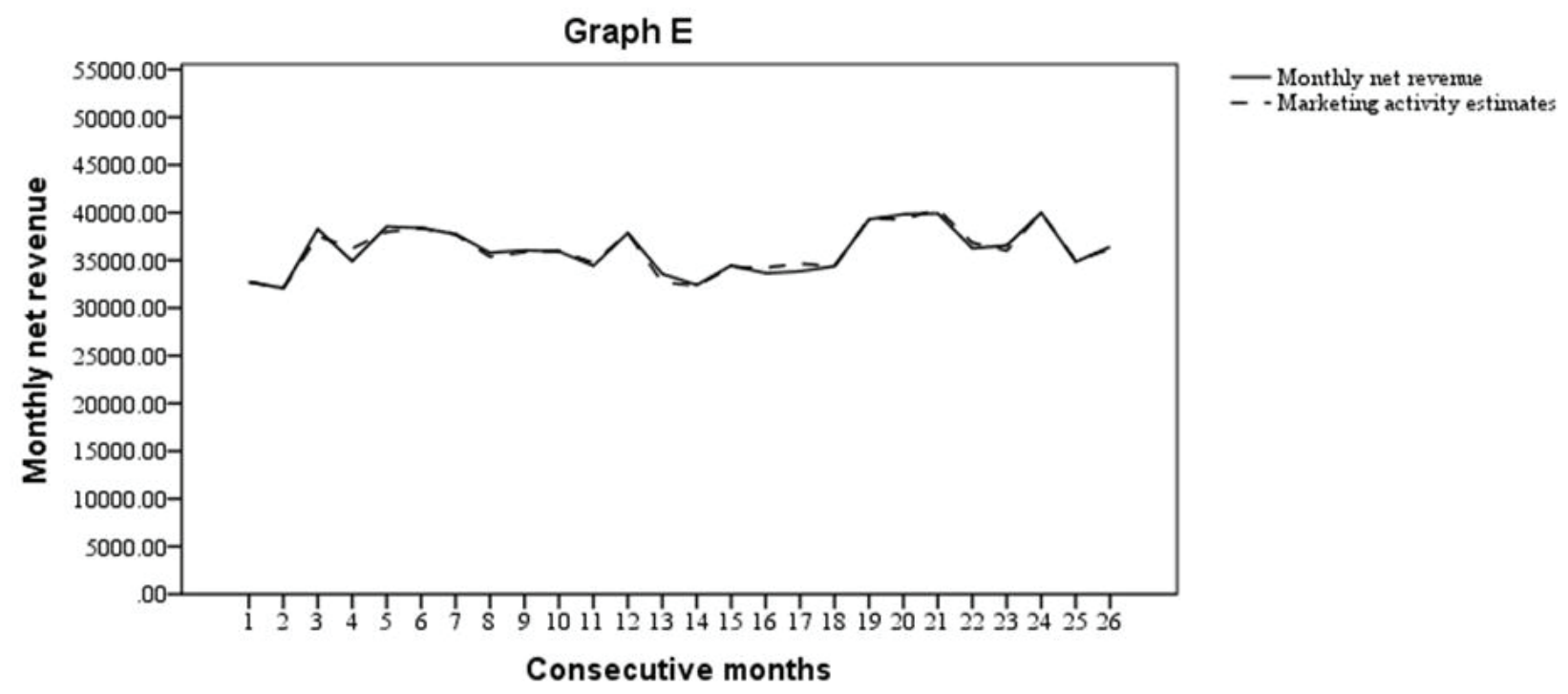

Figure 3. Graph of temporal relationship (months) between aggregated marketing activity estimates and revenue

Source: Database

\section{$5 \cdot 3$ Effect of monthly marketing activities estimates on profitability, controlling the cost of products}

To analyze the effectiveness of marketing activities in terms of profitability (returns on sales) in a more precise way, the cost of products was controlled and a stationary model with time series was also used, involving the first difference both for the explained variable and for the explanatory variables. Additionally, all the variables were transformed into logarithms, illustrating changes in percentage points.

The marketing activities estimate is effective in terms of increasing profitability (Table 
4). A $1 \%$ increase generates a $1.64 \%$ increase in returns on sales. However, a $1 \%$ increase in cost of products generates a $2.34 \%$ reduction in profitability. Thus, if the retail micro-business increases the costs of products, it needs to increase its marketing activities more than proportionally in order to compensate for the increase in costs.
Therefore, despite the effectiveness of the marketing activities in terms of net accounting profit, they are not enough to cover the costs of products in this micro-enterprise. Both explanatory variables present an immediate effect on sales returns in the current month and lasts only during that same month.

Table 4

Effect of marketing activity estimates and costs of products on profitability (micro-macro)

\begin{tabular}{lcc}
\hline & \multicolumn{2}{c}{ EV: Profitability (in log) } \\
\cline { 2 - 3 } Monthly company marketing activities (log and difference 1) & Estimate & Standard Error \\
Cost of products and merchandise (log and difference 1) & $1.64^{*}$ & 0.30 \\
\hline $\mathrm{R}^{2}$ Stationary & $-2.34^{*}$ & 0.40 \\
Bic Normalized & $89.40 \%$ \\
Ljung-Box Q (18) & -5.18 \\
\hline
\end{tabular}

${ }^{*} \mathrm{p} \leq 0.01$

With an explained stationary variance of $89.40 \%$, both explanatory variables can be used to predict returns on sales.

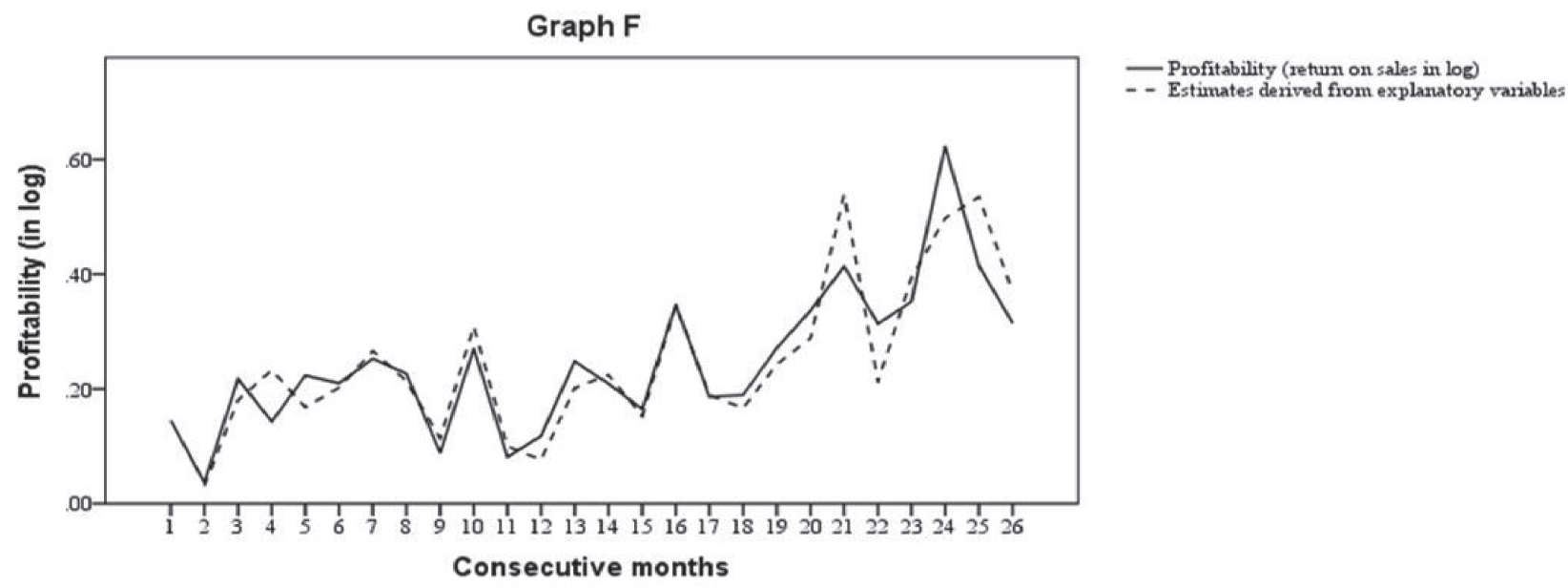

Figure 4. Graph showing temporal relationship (months) between marketing activity estimates, costs of products and profitability

Source: Database 


\section{Discussion}

The present paper demonstrates that the marketing activities generate a dynamic effect both on product sales and company net revenue and profitability. This shows that if the microenterprise maintains its operations over time, it is because the marketing activities carried out generate a minimally positive effect on product sales. Activities that are typically carried out by small enterprises (Newman \& Cullen, 2002; Runyan \& Droge, 2008) focus on the day-to-day business. This study investigated the approach for the micro-micro level of analysis - product sales, supporting Hypothesis 1. It bears mentioning that unlike studies that list the costs of marketing activities (Ward, 2013), this study found results of this relationship by comparing the incidence and/or execution of an activity itself, and is thus more useful for commercial decisions (Leeflang et al., 2015).

At the same time, these marketing activities, in an aggregated way, dynamically alter the financial consequence for the company by positively affecting revenue, and, also profit. This supports Hypotheses 2 and 3, respectively. Thus, aggregation of the data on a product level to a company level does not need to obey the product purchase cycle (Hanssens et al. 2003), but, otherwise, be adapted for decision making [decisions regarding cash flow (Hanssens \& Dekimpe, 2008)].

Particularly within the micro-micro relationship, the price of sales, alterations in store ambience and increases in product assortment are, respectively, the marketing activities that most generate effects over the sales of each product in a dynamic way. This finding is not new in the literature. Price-elasticity has traditionally been shown to be one of the biggest influencers of sales (Bijmolt et al., 2005), especially products sold in retail (Klapper \& Zenetti, 2012). Store ambience and product brands assortment have also been evaluated recently as sales influencers or performance indicators derived from product level sales (Mishra et al., 2014; Morgado \& Benito, 2015; Porto \& Oliveira-Castro, 2015; Porto \& Silva, 2014; Shields, 2006). Therefore, the result from the micro-micro relationship only proves that the marketing activities carried out by microbusinesses also generate effects over sales, just as those carried out by large companies do.

It bears mentioning that payment by credit card, promotional materials, and commission given to sales assistants also generate a positive effect on product brand sales, but in a much less impactful way than alterations in price, product assortment and store ambience. Although the study did not test long term effects, this result corroborates with studies that have found that product, place, and price generate bigger effects than promotional actions (Ataman et al., 2010).

Considering the results regarding different levels of analysis (micro-macro), the aggregated estimate of total marketing activities on the micro level predicts company revenue and profitability on a monthly basis (macro level). Thus, a micro level variable has quite a dynamic influence over a macro level variable. This offers an approach for addressing how to make studies between levels with the micro-macro combination, using real market data (Croon \& Van Veldhoven, 2007) in order to test the effectiveness of company behavior, even in micro-enterprises.

Thus, using an aggregated score to capture the micro level effects on the aggregated level, contributes empirically to testing the predictive power of marketing activities conceived by means of their execution (instead of only by means of their costs - Raman et al., 2012) in relation to company financial performance. The method used here implies gathering secondary data (financial and product related) during the execution periods for each activity, to internally validate the relationship investigated. As many of these retail activities are recorded daily, aggregation of the data needs to be done by investigating the effect on the explained variable on the same (micromicro) analysis level, and, also using parameters comparable to the macro explained variable, 
which is the focus of this analysis. This study used an aggregation of estimates (latent scores) of the micro level explanatory variable to relate it with the macro level explained variables. This method appeared to adjust well to the data used.

The negative effect of the cost of physical resources over profitability supports Hypothesis 4. Cost was stronger than marketing activities. Thus, if the firm's current behaviors regarding marketing are proportionally increased in relation to the cost of products, the company business will not be sustainable. The company would therefore not be efficient (Guissoni \& Neves, 2013). For this to happen, it would need to increase the execution of its activities by approximately 30\% to reach the level of influence of increasing cost. Therefore, if the micro-business studied executes the same intensity of marketing activities as the costs of products, the former would not be enough to cover the latter.

\section{Conclusion}

This paper demonstrated the effectiveness of marketing activities in dynamically generated products sales, revenue and profitability in a microenterprise. All the four hypotheses in the paper were confirmed. This showed that analytical techniques of Market Response Model (Hanssens et al., 2003) can also be used to identify the Marketing Productivity Chain (Rust et al., 2004) in micro-enterprises, providing explanations regarding financial performance. It also demonstrated that the relationships between different levels of analysis, specifically micromacro, can be useful for forecasting the revenue and profitability of companies.

Thus, owners and managers of for-profit micro-businesses can evaluate the effectiveness of the marketing activities they carry out in a dynamic and pragmatic way for corrective decision making. Moreover, it is possible to compare this effectiveness with the costs of selling products to discover whether these activities are also efficient. This study contributes methodologically in terms of the way it carries out this test.
The results can be generalized for any company that carries out marketing for supplier products and that aims to increase revenue and profitability without, however, being concerned with long term effects of marketing actions. This situation typically occurs in micro-enterprises in stationary markets. Nevertheless, the sample limitation on the macro level could lead to problems in generalizing the findings. Moreover, micro-enterprises can plan and execute other marketing activities besides those that were investigated here.

In general terms, the statistical techniques used in this study investigated the linear dynamics of the relationship between marketing and finance; yet, there may be nonlinear effects and/or non-recursive effects and/or evolutionary effects that are not investigated here. Future research could address these relationships, providing further details regarding the effect of marketing on company financial performance.

\section{Note:}

1 This research received financial support from the Brazilian National Council for Scientific and Technological Development (Conselho Nacional de Desenvolvimento Científico e Tecnológico/CNPq).

\section{References}

Akroush, M. N. (2011). The mediation effect of marketing expertise on marketing assets and capabilities toward financial performance. International Journal of Internet Marketing and Advertising, 6(4), 373-412.

Asgarnezhad Nouri, B., Sanayei, A., Fathi, S., \& Kazemi, A. (2015). The effect of marketing tactical capabilities on the financial performance of the firms: Meta-analysis approach. Iranian Journal of Management Studies, 8(1), 73-96.

Ataman, M. B., Van Heerde, H. J., \& Mela, C. F. (2010). The long-term effect of marketing strategy on brand sales. Journal of Marketing Research, 47(5), 866-882. 
Bijmolt, T. H., Heerde, H. J. V., \& Pieters, R. G. (2005). New empirical generalizations on the determinants of price elasticity. Journal of Marketing Research, 42(2), 141-156.

Boyd, E., Farris, P., \& Hildebrandt, L. (2004). PIMS and COMPUSTAT data: Different horse for the same course. In: P. Farris \& M. Moore (Eds.), The Profit Impact of Marketing Strategy Project: Retrospect and Prospect (pp. 41-72). Cambridge: Cambridge University Press.

Braghin, F., Higashibara, L. G. I., de Freitas, M. F., Catuchi, Y. A., \& Mancini, R. (2008). Marketing de varejo: $O$ ambiente das farmácias independentes sob o ponto de vista de seus gestores. Trabalho de Conclusão de Curso, Faculdade de Ciências Econômicas e Administrativas de Presidente Prudente, Presidente Prudente, Brasil.

Brooks, N., \& Simkin, L. (2011). Measuring marketing effectiveness: An agenda for SMEs. The Marketing Review, 11(1), 3-24.

Coelho, R. L. F., de Miranda, J. R., Camargo Filho, A., Freitag, M. S. B., \& de Almeida, M. I. S. (2015). Gestão do marketing em micro e pequenas empresas. Revista de Empreendedorismo e Gestâo de Pequenas Empresas, 4(2), 219-250.

Conselho Federal de Farmácia, CFF. (2008). Marketing em farmácias e drogarias. Planejamento Estratégico Empresarial, 1(8), $1-4$.

Cozby, P. C. (2006). Métodos de pesquisa em ciências do comportamento. São Paulo: Atlas.

Croon, M. A., \& Van Veldhoven, M. J. (2007). Predicting group-level outcome variables from variables measured at the individual level: A latent variable multilevel model. Psychological Methods, 12(1), 45-57.
Feng, H., Morgan, N. A., \& Rego, L. L. (2015). Marketing department power and firm performance. Journal of Marketing, 79(5), $1-20$.

Finkelstein, S., \& Peteraf, M. A. (2007). Managerial activities: A missing link in managerial discretion theory. Strategic Organization, 5(3), 237-248.

Floriani, D. E., \& Fleury, M. T. (2012). O efeito do grau de internacionalização nas competências internacionais e no desempenho financeiro da PME brasileira. Revista de Administração Contemporânea, 16(3), 438-458.

Grewal, D., Levy, M., \& Kumar, V. (2009). Customer experience management in retailing: An organizing framework. Journal of Retailing, 85(1), 1-14.

Guia das Farmácias (2014). O que fazer diante tantos produtos? Guia das Farmácias. Produtos para Saúde Correlatos, 21(260), 12-14.

Guissoni, L. A., \& Neves, M. F. (2013). Ensaio sobre a análise de desempenho em marketing e aplicação de métricas. Revista Brasileira de Marketing, 12(4), 201-229.

Hankinson, A. (1991), Small business: Management and performance. London: Avebury.

Hansen, G. S., \& Wernerfelt, B. (1989). Determinants of firm performance: The relative importance of economic and organizational factors. Strategic Management Journal, 10(5), 399-411.

Hanssens, D. M., \& Dekimpe, M. G. (2008). Models for the financial-performance effects of marketing. In: B. Wierenga (Ed.), Handbook of Marketing Decision Models (pp. 501-523). New York: Springer.

Hanssens, D. M., Parsons, L. J., \& Schultz, R. L. (2003). Market response models: Econometric 
and time series analysis (Vol. 12). Norwell: Kluwer Academic Publishers.

Hill, J. (2001). A multidimensional study of the key determinants of effective SME marketing activity. International Journal of Entrepreneurial Behavior \& Research, 7(5), 171-204.

Hitt, M. A., Beamish, P. W., Jackson, S. E., \& Mathieu, J. E. (2007). Building theoretical and empirical bridges across levels: Multilevel research in management. Academy of Management Journal, 50(6), 1385-1399.

Irvine, P. J., \& Pontiff, J. (2009). Idiosyncratic return volatility, cash flows, and product market competition. Review of Financial Studies, 22(3), 1149-1177.

Isaeva, T. N., Safiullin, L. N., Bagautdinova, N. G., \& Shaidullin, R. N. (2013). Aspects of a multilevel study of competitive performance of objects and subjects of economic management. World Applied Sciences Journal, 27(13), 116-119.

Jandaghi, G., Amiri, A. N., Amini, A., \& Darani, M. (2011). Assessment and ranking the effects of marketing mix on flower and plant sale volume. International Journal of Academic Research in Business and Social Sciences, 1(3), 207-219.

Klapper, D., \& Zenetti, G. (2012). Combining micro and macro data to study retailer pricing in the presence of state dependence. In: A. Diamantopoulos, W, Fritz, \& L. Hildebrandt (Eds.), Quantitative Marketing and Marketing Management (pp. 379-400). Wiesbaden: Springer.

Kosan, L. (2014). Accounting for marketing: Marketing performance through financial results. International Review of Management and Marketing, 4(4), 276-283.
Leeflang, P. S., Wieringa, J. E., Bijmolt, T. H., \& Pauwels, K. H. (2015). Building models for markets. New York: Springer.

Lima, M.I.C., \& Porto, R.B. (2012). Efeito prolongado das estratégias de comunicação de marketing e dos indicadores setoriais no faturamento de bares. Revista Brasileira de Marketing, 11(3), 53-74.

Maas, C. J., \& Hox, J. J. (2005). Sufficient sample sizes for multilevel modeling. Methodology, 1(3), 86-92.

Mayntz, R. (2004). Mechanisms in the analysis of social macro-phenomena. Philosophy of the Social Sciences, 34(2), 237-259.

McCartan-Quinn, D., \& Carson, D. (2003). Issues which impact upon marketing in the small firm. Small Business Economics, 21(2), 201-213.

McDonald, M., Mouncey, P., \& Maklan, S. (2014). Marketing value metrics: A new metrics model to measure marketing effectiveness. London: Kogan Page Publishers.

Mintz, O., \& Currim, I. S. (2013). What drives managerial use of marketing and financial metrics and does metric use affect performance of marketing-mix activities? Journal of Marketing, 77(2), 17-40.

Mishra, H. G., Sinha, P. K., \& Koul, S. (2014). Impact of store atmospherics on customer behavior: Influence of response moderators. Journal of Business and Management, 20(1), 45-66.

Mizik, N. (2014). Assessing the total financial performance impact of brand equity with limited time-series data. Journal of Marketing Research, 51(6), 691-706.

Monteiro, J. M., \& Barbosa, J. D. (2011). Controladoria empresarial: Gestão econômica 
para as micro e pequenas empresas. Revista da Micro e Pequena Empresa, 5(2), 38-59.

Morgado, Á. G., \& Benito, Ó. G. (2015). Merchandising at the point of sale: Differential effect of end of aisle and island. Business Research Quarterly, 18(1), 57-67.

Morgan, N.A. (2012). Marketing and business performance. Journal of Academy of Marketing Science, 4O(1), 102-119.

Newman, A. J., \& Cullen, P. (2002). Retailing: Environment \&operations. London: Cengage Learning EMEA.

Nicolau, I. (2013). The evolution of the marketing concept. Knowledge Horizons-Economics, 5(3), 154-156.

Oliveira Filho, J. B. D. (2013). O mercado farmacêutico de varejo no Distrito Federal do Brasil de 2000 a 2012. Dissertação de mestrado. Universidade de Brasília, Brasília, Brasil.

Porto, R. B., \& Oliveira-Castro, J. M. (2015). Consumer purchase and brand performance. In: G. Foxall (Ed.), The Routledge companion to consumer behavior analysis, (pp. 175 -201). New York: Routledge.

Porto, R. B., \& Silva, A. T. V. (2014). Efeitos da precificação, da diferenciação e da oferta de valor no desempenho de marcas em contextos competitivos. Revista de Administração, 49(1), 103-115.

Raman, K., Mantrala, M. K., Sridhar, S., \& Tang, Y. E. (2012). Optimal resource allocation with time-varying marketing effectiveness, margins and costs. Journal of Interactive Marketing, 26(1), 43-52.

Roberts, J. H., Kayande, U., \& Stermersch, S. (2013). From academic research to marketing practice: Exploring the marketing science value chain. International Journal of Research in Marketing, 31(2), 127-140.

Runyan, R. C., \& Droge, C. (2008). A categorization of small retailer research streams: What does it portend for future research?. Journal of Retailing, 84(1), 77-94.

Rust, R.T., Ambler, T., Carpenter, G.S., Kumar, V., \& Srivastava, R.K. (2004). Measuring marketing productivity: Current knowledge and future directions. Journal of Marketing, 68(4) 76-89.

Sarquis, A. B., Cittadin, J., de Morais, A. S. A., Tondolo, R. D. R. P., \& Santos, E. (2016). $\mathrm{O}$ estado da arte do tema marketing para pequenas empresas: Um estudo bibliométrico da produçáo científica nacional. Revista Brasileira de Gestão e Inovação, 3(3), 109-134.

Serviço Brasileiro de Apoio às Micro e Pequenas Empresas, Sebrae (2015). Anuário do trabalho na micro e pequena empresa: 2015. Departamento Intersindical de Estatística e Estudos Socioeconômicos. Brasília: Sebrae.

Shields, J. (2006). Effects of atmospherics on revenue generation in small business restaurants. Journal of Business and Entrepreneurship, 18(2), 79-87.

Siddhanta, S., \& Banerjee, N. (2014). The impact of promotional mix on profit in the B2B sector. Marketing Intelligence \& Planning, 32(5), 600-615.

Srivastava, R. K., Shervani, T. A., \& Fahey, L. (1998). Market-based assets and shareholder value: A framework for analysis. The Journal of Marketing, 62(1), 2-18.

Stock, J. H., \& Watson, M. W. Econometria. São Paulo: Pearson Education Brasil, 2004.

Supplementary Law N. 139, from November $10^{\text {th }} 2011$ (2011). Changes provisions of 
Complementary Law No 123, from December $14^{\text {th }}$ 2006, and give other arrangements. Brasília. Recovered on December 26, 2016, from http://www.planalto.gov.br/ccivil_03/ leis/LCP/Lcp139.htm\#art5

Vorhies, D. W., Orr, L. M., \& Bush, V. D. (2011). Improving customer-focused marketing capabilities and firm financial performance via marketing exploration and exploitation. Journal of the Academy of Marketing Science, 39(5), 736-756.

Ward, K. (2013). Financial aspects of marketing. New York: Routledge.
Wieseke, J., Lee, N., Broderick, A. J., Dawson, J. F., \& Van Dick, R. (2008). Multilevel analysis in marketing research: Differentiating analytical outcomes. Journal of Marketing Theory and Practice, 16(4), 321-340.

Wilkie, W. L., \& Moore, E. S. (2007). What does the definition of marketing tell us about ourselves? Journal of Public Policy \& Marketing, 26(2), 269-276.

Zait, L. (2009). The process of marketing management-between the management marketing activities and the operational marketing. Studies and Scientific Researches. Economics Edition, 14, 129-136.

\section{Supporting agencies:}

CNPq: 484425/2013-7

\section{About the authors:}

1. Rafael Barreiros Porto, PhD in Behavior Science, University of Brasilia, Postgraduate Program in Administration, Brasília, Brazil. Email: rafaelporto@unb.br

2. Rafaela da Rocha Costa, Bachelor in Administration, University of Brasília, Faculty of Economics, Administration, Accounting and Public Policy Management, Brasília, Brazil. Email: rafa89rocha@gmail.com 3. Eluiza Alberto de Morais Watanabe, PhD in Business Management, University of Brasília, Faculty of Economics, Administration, Accounting and

Public Policy Management, Brasília, Brazil. Email: eluizaw@gmail.com

\section{Contribution of each author:}

\begin{tabular}{lccc}
\hline Contribution & Rafael Porto & Rafaela Costa & Eluiza Watanabe \\
\hline 1. Definition of research problem & $\sqrt{ }$ & $\sqrt{ }$ & $\sqrt{ }$ \\
2. Development of hypotheses or research questions & $\sqrt{ }$ & $\sqrt{ }$ \\
(empirical studies) & $\sqrt{ }$ & $\sqrt{ }$ \\
3. Development of theoretical propositions (theoretical Work) & $\sqrt{ }$ & $\sqrt{ }$ \\
4. Theoretical foundation/ Literature review & $\sqrt{ }$ \\
5. Definition of methodological procedures & $\sqrt{ }$ \\
6. Data collection & $\sqrt{ }$ \\
7. Statistical analysis & $\sqrt{ }$ \\
8. Analysis and interpretation of data & $\sqrt{ }$ \\
9. Critical revision of the manuscript & & $\sqrt{ }$ \\
10. Manuscript Writing & & \\
\hline
\end{tabular}

